\title{
The Enhancement of Work Motivation in Agrarian Affair Office of Makassar City, South Sulawesi, Indonesia
}

\author{
Aslinda1, Muhammad Guntur², Henni Zainal', \\ Andi Cudai Nur ${ }^{4}$, Syurwana Farwita ${ }^{5}$ \\ 1'Universitas Negeri Makassar, ${ }^{2}$ Universitas Negeri Makassar (email: m.guntur@unm.ac.id), \\ ${ }^{3}$ Universitas Indonesia Timur (email: henni_zainal@yahoo.com), ${ }^{4}$ Universitas Negeri Makassar, \\ ${ }^{5}$ Universitas Indonesia Timur (email: syurwanafarwita@yahoo.co.id)
}

\begin{abstract}
The employees' motivation is considered low because employees do not comply with applicable regulations. Even though in terms of income and benefits provided considered quite adequate, the low level of motivation of course will affect the work results of employees. The purpose of this study is to provide an overview of increased work motivation at the Agrarian Affair Office of Makassar city. This research is quantitative research with explanatory objectives, namely to explain the causal relationship (influence) of variables increasing work motivation at the Agrarian Affair Office of Makassar city. To measure the variables in this study, questionnaires are used. The results showed that work motivation at the Agrarian Affair Office of Makassar city was in a fairly good category. The implications of this research are to increase work motivation at the Agrarian Affair Office of Makassar city.
\end{abstract}

\section{Keywords:}

enhancement of motivation; achievement; appreciation; challenge; responsibility

\section{Introduction}

Work motivation is a form of stimulation for employees to trigger enthusiasm to work optimally. To arouse the motivation of work of employees, of course, it is much related to the output that is in the entrepreneur himself as a form of character in work. For everyone, work motivation will tend to be different, in different times and places. One of the ways in which public service motivation has been played into research by economists is the specification of altruism, the willingness of individuals to reciprocate without themselves (Perry 2015). This means that work motivation for each person is largely determined by the factors that influence it. Likewise, a person's work motivation can be observed from the work effectiveness and work results that show high performance so that work motivation is always work-oriented. Motivated employees are the cornerstones of all organizations, as 
work motivation is one crucial determinant of individual and organizational performance (Anderfuhren-biget, Varone, and Giauque n.d.).

(Siswanto 2005) proposes indicators of work motivation can be seen from several aspects, namely:

(1) Achievement

A person who has the desire to excel as a necessity will certainly encourage themselves to the maximum level to achieve the goals or desires. The desire to achieve one will make various efforts with all the risks that must be faced.

(2) Awards

With the appreciation of the leadership or co-workers for an achievement achieved is a strong motivator. Measurement of an achievement will provide higher inner satisfaction than appreciation of material forms or gifts. Awards or recognition could be in the form of a certificate of appreciation or in the form of goods or bonuses awarding.

(3) Challenges

A target that is not challenging or can easily be achieved is usually activity is not able to become a motivator, and even tends to make routine activities. The challenge for ordinary challenges will lead to activity will be able to produce excitement activities to overcome them.

(4) Responsibility

A sense of belonging will lead to motivation to feel responsible. The sense of responsibility is based on the awareness of the tasks that are charged to be carried out to the maximum in accordance with their abilities and with the support of high awareness in carrying out their tasks, of course, they will be able to produce maximum results.

(5) Development

The development of one's abilities both from work experience or opportunities to progress can be a powerful motivator for employees to work harder and more passionately. Moreover, the development of organizations is always associated with achievements or work activities achieved by employees. 


\section{(6) Engagement}

Feeling involved in the decision-making process can make employees feel valued so that they always want to do the best for the organization where they work. Feeling involved will foster a sense of belonging, responsibility is a challenge that must be maintained through achievement of participation in developing business and selfdevelopment.

(7) Opportunities.

Opportunities to advance in the form of an open career path hierarchy under the top management hierarchy will be sufficient motivators for employees to achieve progress or improve their fate. In other words, with the ability will give enthusiasm for employees to work optimally in accordance with their abilities.

(Wahjosumidjo 1987) divides motivation theory into two types of genre, namely:

1) Satisfaction Theory (Content Theory)

Basically this theory emphasizes the importance of knowledge of the factors in the subordinates that cause them to behave. This theory also answers the question:

- What needs are needed by subordinates to achieve satisfaction.

- What encouragement that causes the subordinate to behave.

2) Process-Based Theory

In this theory the emphasis is on providing answers to questions:

- How can the subordinates be motivated?

- With what goals the subordinates can be motivated?.

In addition to these two theories there are also people who distinguish motivation theory into other motivational theories, namely:

1) Instrumental Theory, which includes exchange theory (Exchange Theory) and expectation theory (Expectancy Theory).

2) Needs Theory, based on observations of the results of these experts, there are quite a number of motivational theories that are interesting to put forward such theories such as: 
- Hedonism Theory

It is a point of view that says that humans are essentially beings who are concerned with life full of joy and luxury. If humans are faced with alternatives, they will tend to choose the direction of action that will increase pleasure and avoid the direction of unpleasant actions that can lead to illness, suffering, or death. The implication of this theory is that there are assumptions that many employees do not want to work well, who are lazy to work, like to avoid difficult jobs, and enjoy getting high wages.

- Instinct theory

Instinct theory connects human behavior with various instincts. Basically, humans have three basic instincts, namely instinct to defend themselves, instinct to develop themselves, and instinct to develop types. Human habits, actions and behavior are driven by these three instincts. Therefore, to motivate people to pay attention to which instincts are the focus of attention.

- Reaction Theory Studied (Culture)

Another theory states that human behavior is not based on instincts, but rather on patterns of behavior that are learned from culture, where a person lives. People learn most from the cultural environment in which they live. On that basis if a leader will motivate his subordinates, then the leader must know the background of the life and culture of the people he leads.

- Theory of Driving Power

The "driving force" flow is a compromise between "instinct" and the flow of "reactions learned". Driving power is a kind of instinct, but only a broad force of force towards a general direction. Therefore, if you want to motivate, you must base on two principles, namely instincts and reactions that are learned from the environment culture.

- Needs Theory

The theory of motivation that is now widely adopted by people is the theory of needs. This theory assumes that human action in essence is to fulfill needs. Therefore, if the leader wants to motivate his subordinates, he must know what the needs of his subordinates are. 
By looking at some of the descriptions above, work motivation is one of the factors that greatly affect the productivity of labor in an organization or agency. This needs to be understood because each workforce has a different personality, character, or character, so the needs of each employee can be the same but the desires of each employee are certainly not the same, this can be influenced by one's tastes, habits and environment. Therefore, someone will want to work diligently with hope, they can fulfill their needs and desires from the results of their work. According to (Hasibuan 2000) there are several goals of giving motivation are as follows:

1) Encourage employee enthusiasm and enthusiasm

2) Increasing employee morale and job satisfaction

3) Increase work productivity

4) Creating a good working atmosphere and relationship

5) Increase creativity and employee participation

6) Enhancing employees' sense of responsibility towards the work that carried out

\section{Research Method}

This research includes quantitative research with explanatory objectives. The population of this research was the all 70 employees of the Agrarian Affair Office of Makassar City. In order that this study can provide generalizations with a very small error rate, and considering the population is only 70 people, then in this study a sampling technique is used that is saturated sampling, where all members of the population are sampled. Thus the number of samples in this study were 70 people. Data collection techniques are observation, questionnaire, interview and documentation techniques. The data analysis technique used in this study is descriptive statistical analysis techniques and inferential statistical analysis techniques that aim to examine the research variables.

\section{Result and Discussion}

1) Description of Work Motivation (Y)

Qualifications of the quality of respondents' answers regarding work motivation at the Agrarian Affair Office of Makassar City are also based on the categories as done to find out disciplinary guidance. The categories intended are based on categories: namely very good, 
good, good enough, and not good. For more details about the level of work motivation can be seen in Table.

The results showed that work motivation at the Agrarian Affair Office of Makassar City was in a fairly good category. This gives an indication that employees at the Agrarian Affair Office of Makassar City have a fairly good level of motivation which is certainly inseparable from the discipline guidance that has been given. Good enough work motivation can be seen from work motivation indicators namely:

a) Achievement; on aspects of achievement indicators show that employee motivation is in a fairly good category where employees have the motivation to achieve maximum work results.

b) Awards; the aspects of the award indicator are in a fairly good category where the leader rewards employees who are diligent and achievers.

c) Challenges; in the aspect of challenge indicators in the fairly good category shows that the challenges sometimes faced by employees in each of their jobs do not discourage employees at the Agrarian Affair Office of Makassar City, but the challenges or problems faced are used as an impetus to issue all their abilities in dealing with any issues that in the work environment.

d) Responsibilities; on the aspects of responsibility indicators held by employees at the Agrarian Affair Office of Makassar City are in a fairly good category where employees prioritize their responsibilities to agencies, besides that leaders also sometimes submit job responsibilities to employees who show that the leadership believes in employees in completing job responsibilities given by the leader.

e) Development; on the aspect of development indicators based on the results of the study in the fairly good category. This is inseparable from the freedom given by leaders to employees to develop their abilities, especially in matters relating to work.

f) Engagement; in the aspect of indicator involvement is in the fairly good category. This can not be separated from the involvement of leaders in decision making.

g) Opportunities; on the aspect of opportunity indicators are in the fairly good category. Where employees have the opportunity to step forward. 
Frequency Distribution Table and Percentage of Work Motivation

\begin{tabular}{rrccc}
\hline No & Interval Score & Category & Frequency & $\begin{array}{l}\text { Percentage } \\
(\%)\end{array}$ \\
\hline 1 & $51-62$ & Very good & 0 & 00,00 \\
2 & $39-50$ & Good & 19 & 27,14 \\
3 & $27-38$ & Fairly good & 51 & 72,86 \\
4 & $15-26$ & Bad & 0 & 00,00 \\
\hline & Total & & 70 & 100,00 \\
\hline
\end{tabular}

Source: Results of Data Questionnaire

The table above shows that out of 70 respondents, there were 19 respondents $(27.14$ percent) who stated that their motivation to work at the Agrarian Affair Office of Makassar City was good, 51 respondents (72.86 percent) stated that work motivation was quite good, and there were no respondents who stated that work motivation in the category of very good and not good. Work motivation at the Agrarian Affair Office of Makassar City belongs to a fairly good category, where the average value of 36.31 is in the range 27-38 with a standard deviation of 3.22. This illustrates that work motivation at the Agrarian Affair Office of Makassar City is quite good, in terms of several indicators that can affect work motivation.

Motivation given to employees, leaders are often faced with factors that support and inhibit the provision of motivation to employees. Likewise in giving motivation to employees at the Agrarian Affair Office of Makassar City. According to the Head of Administration Section, Mr. Sa'pang Allo, S.H, based on the results of an interview conducted on January 25, 2017 said that: "The level of motivation of employees at the Agrarian Affair Office of Makassar City still needs to be improved because some employees are less aware of the meaning and importance of discipline. Even though we have made various efforts such as coming to work early, giving verbal reprimand and written reprimand for employees who often violate office rules, and giving awards to employees who are diligent andbrilliant. "

With the existence of high work motivation the possibility of employees to achieve work performance will be even greater. The increase in employee work motivation in general has not shown satisfactory results by looking at the behavior of employees who lack discipline in the implementation of tasks assigned to them. 
The result of normality assessment of research data

\begin{tabular}{lcccc}
\hline Variable & $X^{2}$ calculation & $X^{2}$ table & df & Information \\
\hline Work Motivation & 17,600 & 22,362 & 13 & Normal \\
\hline
\end{tabular}

Source: Results of Statistical Analysis through SPSS 23 Program.

Work motivation variable is obtained by Chi Square value calculated at 17,600 with df of 13. The price is compared with Chi Square table price of 22,362, with df of 13 and significant level of $5 \%$. Because the Chi Square price is smaller than the Chi Square table price $(17,600<22,362)$, the distribution of work motivation data is normal.

The results showed that work motivation at the Agrarian Affair Office of Makassar City was in a fairly good category. This gives an indication that employees at the Agrarian Affair Office of Makassar City have a fairly good level of motivation which is certainly inseparable from the discipline guidance that has been given. The research is in line with research (Jayaweera 2015). The study shows that job performance is very much influenced by work environment and motivation of workers. The study also confirms the mediating role of motivation in working conditions and job performance relationships within regard to hotel workers. Good enough work motivation can be seen from work motivation indicators namely:

1. Achievement; on aspects of achievement indicators show that employee motivation is in a fairly good category where employees have the motivation to achieve maximum work results.

2. Awards; the aspects of the award indicator are in a fairly good category where the leader rewards employees who are diligent and achievers.

3. Challenges; in the aspect of challenge indicators in the fairly good category shows that the challenges sometimes faced by employees in each of their jobs do not discourage employees at the Makassar City Land Office but the challenges or problems faced are used as an impetus to issue all their abilities in dealing with any issues that in the work environment.

4. Responsibility; on the aspects of responsibility indicators held by employees at the Makassar City Land Office are in a fairly good category where employees prioritize their responsibilities to agencies, besides that leaders also sometimes submit job 
responsibilities to employees who show that the leadership believes in employees in completing job responsibilities given by the leader.

5. Development; on the aspect of development indicators based on the results of the study in the fairly good category. This is inseparable from the freedom given by leaders to employees to develop their abilities, especially in matters relating to work.

6. Involvement; in the aspect of indicator involvement is in the fairly good category. This cannot be separated from the involvement of leaders in decision making.

7. Opportunities; on the aspect of opportunity indicators are in the fairly good category, where the employees have the opportunity to go further.

Work motivation is strongly correlated that is influenced by the good work motivation of employees in carrying out their duties at the Agrarian Affair Office of Makassar City. This was supported by previous research which stated that the results showed that labor motivation was in the high category. The fact that the lab is eager is completing the main task. Leadership ability to encourage workers in achievement appears on the reward for the achievers (Zainal 2017).

\section{Conclusion}

The work motivation at the Agrarian Affair Office of Makassar City is in a fairly good category in terms of aspects of achievement, appreciation, challenge, responsibility, development, and involvement. It is recommended that work motivation at the Agrarian Affair Office of Makassar City should be improved.

\section{References}

Anderfuhren-biget, Simon, Frédéric Varone, and David Giauque. n.d. "Motivating Employees of the Public Sector: Does Public Service Motivation Matter?" (January 2015):37-41.

Hasibuan, Malayu SP. 2000. Manajemen Dasar, Pengertian Dan Masalah. Jakarta: Bumi Aksara. Jayaweera, Thushel. 2015. “Impact of Work Environmental Factors on Job Performance, Mediating Role of Work Motivation : A Study of Hotel Sector In." 10(3):271-78.

Perry, James L. 2015. “Public Service Motivation Research: Achievements, Challenges, and 
Future Directions." (October):692-99.

Siswanto, H. 2005. Pengantar Manajemen. Jakarta: Bumi Aksara.

Wahjosumidjo. 1987. Kepemimpinan Dan Motivasi. Jakarta: Ghalia Indonesia.

Zainal, Henni. 2017. "Influence of Work Motivation and Discipline on Work Productivity." 149(Icest):25-27. 